\title{
CHANGES IN MICROMORPHOLOGICAL CHARACTERS OF PLATANUS ORIENTALIS L. LEAVES IN TURKEY
}

\author{
SEVIK, H. ${ }^{1}-$ CETIN, M. ${ }^{2 *}$ OZTURK, A. ${ }^{3}-$ Yigit, N. ${ }^{3}-$ KARAKUS, O. ${ }^{4}$ \\ ${ }^{l}$ Department of Environmental Engineering, Faculty of Engineering and Architecture, \\ Kastamonu University, Kastamonu, Turkey \\ ${ }^{2}$ Department of Landscape Architecture, Faculty of Engineering and Architecture, Kastamonu \\ University, Kastamonu, Turkey \\ ${ }^{3}$ Department of Forest Engineering, Faculty of Forestry, Kastamonu University \\ Kastamonu, Turkey \\ ${ }^{4}$ Programs of Sustainable Agriculture and Natural Plant Resources, Institute of Science, \\ Kastamonu University, Kastamonu, Turkey \\ *Corresponding author \\ e-mail: mcetin@kastamonu.edu.tr \\ (Received 19 $9^{\text {th }}$ Jan 2019; accepted 29 $9^{\text {th }}$ Mar 2019)
}

\begin{abstract}
In this study, it is aimed to determine the variation of some leaf characters of Platanus orientalis L. depending on the climate type. For this purpose, in a country dominated by three climate types (Terrestrial, Black Sea and Mediterranean), leaves samples of Platanus orientalis trees were collected. Scaled images were obtained with the help of electron microscope (SEM = Scanning Electron Microscope) of collected leaf samples. Thus, with measurements made on these images, stoma length $(\mu \mathrm{m})$, stoma width $(\mu \mathrm{m})$, por length $(\mu \mathrm{m})$, por width and stoma density $\left(1 \mathrm{~mm}^{2}\right.$ area). The obtained data were evaluated as statistic and the change of these characters according to climate type and city was evaluated. In addition, by applying correlation analysis to the data, it was attempted to determine the relations between the subject characters and climate data. As a result of the study, no significant effect of the climate could be detected on the characteristics examined. This situation can be interpreted that morphological characteristics are shaped by many environmental factors and genetic structure besides climate. The authors suggest an increase and diversification in studies on the subject in order to determine how and under which conditions micromorphological characteristics are shaped. For this reason, it can be shown that the subjects of the study are collected from the individuals which were primarily raised for landscaping, and the practices in landscape studies change the micro ecological conditions in a clear way. Keywords: climate, correlation, flora, plant, landscape plant
\end{abstract}

\section{Introduction}

In parallel with the rapid increase in urbanization across the globe, green areas are destroyed. However, the increase in the average global incomes and awareness levels of people has led to more efforts and legislations to preserve and increase green areas wherever possible. This is evident in major cities around the world where local authorities are planning to turn their cities greener by announcing schemes and plans to plant six and seven-figure trees in the short and long terms. The importance of plants and trees cannot be overstressed. Their environmental and social benefits such as reducing air and noise pollution, balancing the climate, and contributing to the ecosystem are just a few of many (Cetin and Sevik 2016a,b; Cetin et al., 2017). Furthermore, they perform many functions such as being an economic resource, reducing the speed of the wind and supporting wildlife (Kantarc1 et al., 2011; Özel, 
2008; Ertuğrul et al., 2014). In fact, one of the factors that affect the value of properties in cities nowadays is the amount of green areas and their proximity to them (Tilki et al., 2008; Erna, 2009; Ökmen and Yurtsever, 2010; Yiğit et al., 2014; Öztürk et al., 2017).

When designing open green places in urban areas, plant species, composition, cultivar, and even form are of great importance besides their sizes. In addition to their functional purposes, plants are desired to be aesthetically valuable, and more often that not, people tend to prefer non-native plants. As a result of this, plant species are used outside of their natural distribution areas, which is a situation frequently encountered in landscape architecture. They are confronted with stress factors arising from different habitats (Sevik and Cetin, 2016; Sevik et al., 2017, 2018; Cetin and Sevik 2016a,b; Cetin et al., 2017; Turkyilmaz et al., 2018a, b, c).

It is possible that the stress that may occur in plants as a result of their cultivation in the climatic conditions they are not accustomed to, may affect their micromorphological features that are not visible as well as their morphological features that are visible (Sevik and Cetin, 2015; Sevik et al., 2017, 2018; Cetin et al., 2018a, b; Kaya et al., 2018) because Turkey is under the influence of three main climates, which are quite different from each other. These climate types include the Black Sea climate type, continental climate type, and Mediterranean climate type. The effects of these climate types are combined with topographical conditions, resulting in many different types of local climates (Cetin et al., 2018a; Akkemik, 2014). According to the results of the study, the micromorphological characteristics of the areas working on the climate of the cities of the climate conditions or even the microclimate conditions of the areas of the plant is more effective than the main climate type. In this study, it has been shown that the environmental conditions affect the micromorphological characteristics of the leaves. The results of the study show that the local and micro-conditions are more effective on the micromorphological characteristics of the leaves than the main climate type. In landscape studies, there are many plants grown in the area where all three climate types are dominant. These plants are not morphologically different from each other. However, there is not enough information about how they differ in morphometric and micromorphological terms. However, these changes can provide insight into many issues, from the stress level of the plant to the habitat and the adaptation level (Sevik et al., 2017). However, in order to determine how these micromorphological changes should be interpreted, it is necessary to determine under what conditions these changes are shaped.

In this study, it was aimed to determine the change in some micromorphological characteristics in Platanus orientalis individuals grown in different climate types dominant in Turkey.

\section{Materials and methods}

\section{Materials}

The study was performed on the leaves of Platanus orientalis L. Plane tree (Platanus orientalis L.) belonging to Platanaceae family and is known for its grandeur and longevity. Platanus orientalis is one of the most common plane varieties in the world and it is the most widespread plane tree growing in Turkey. The common name of this variety is oriental plane. Among plane trees, it was the first variety to be discovered. The oriental plane is widely used as an ornamental tree, especially in urban areas and is also cultivated sometimes for timber (Guler et al., 2017). 
Each of the city areas from each of the leaves collected from each leaf and each leaf was made from one to three pieces. Leaf specimens are collected from mature trees but it can be stated that the trees are at least 50-60 years of age.

Platanus orientalis (Oriental plane) leaves were collected from the areas dominated by the three climate types prevailing in Turkey. The Black Sea climate, which is one of the climate types prevailing in Turkey, is defined as wet and humid every season, while the Mediterranean climate has dry and hot summers as well as warm and rainy winters. In continental climate, summers are hot and dry, while winters are cold and snowy (Karakus, 2018). However, there are huge differences between the climate data of the cities in the regions where these climate types are dominant. The general climate characteristics of the cities included in the study were examined separately, and average temperature (Ta), average maximum temperature (Tmax), average minimum temperature (Tmin), average sunshine duration (ASD), average number of rainy days (ANRD), monthly average total precipitation (MATP), maximum temperature (MaxT) and minimum temperature (MinT) values obtained from the records of the General Directorate of Meteorology are presented in tables (URL, 1). The average meteorological data of the cities included in the study are given in Table 1.

Table 1. Annual average meteorological data of the cities included in the study

\begin{tabular}{c|c|c|c|c|c|c|c|c|c}
\hline & \multicolumn{3}{|c|}{ Black Sea climate type } & \multicolumn{2}{c|}{ Mediterranean climate type } & \multicolumn{3}{c}{ Continental climate type } \\
\hline Cities & Bartın & Samsun & Rize & Çanakkale & Antalya & İzmir & Ankara & Kayseri & Van \\
\hline $\mathrm{T}_{\mathrm{a}}\left({ }^{\circ} \mathrm{C}\right)$ & 12.8 & 14.5 & 14.3 & 15.0 & 18.6 & 17.8 & 11.9 & 10.7 & 9.2 \\
$\mathrm{~T}_{\max }\left({ }^{\circ} \mathrm{C}\right)$ & 19.0 & 18.2 & 18 & 19.6 & 24.1 & 22.6 & 17.8 & 18.0 & 14.9 \\
$\mathrm{~T}_{\min }\left({ }^{\circ} \mathrm{C}\right)$ & 7.6 & 11 & 11.1 & 10.7 & 13.7 & 13.4 & 6.2 & 2.9 & 3.6 \\
$\mathrm{ASD}(\mathrm{hrs})$ & 67.2 & 61 & 49.4 & 87.0 & 100.3 & 94.5 & 80.3 & 83.5 & 92.8 \\
$\mathrm{ANRD}$ & 140.0 & 135.6 & 172.5 & 83.6 & 75.1 & 77.7 & 102.3 & 107.2 & 93.0 \\
$\mathrm{MATP}(\mathrm{mm})$ & 1040.5 & 717.5 & 2304.1 & 616.2 & 1066.9 & 695.9 & 387.2 & 384.9 & 388.5 \\
$\mathrm{MaxT}\left({ }^{\circ} \mathrm{C}\right)$ & 42.8 & 39 & 38.2 & 39.0 & 45 & 43 & 41 & 40.7 & 37.5 \\
$\operatorname{MinT}\left({ }^{\circ} \mathrm{C}\right)$ & -18.6 & -9.8 & -7 & -11.5 & -4.6 & -8.2 & -24.9 & -32.5 & -28.7 \\
\hline
\end{tabular}

Ta $\left({ }^{\circ} \mathrm{C}\right)=$ average temperature $\left({ }^{\circ} \mathrm{C}\right)$; Tmax $\left({ }^{\circ} \mathrm{C}\right)=$ average maximum temperature $\left({ }^{\circ} \mathrm{C}\right) ;$ Tmin $\left({ }^{\circ} \mathrm{C}\right)=$ average lowest temperature $\left({ }^{\circ} \mathrm{C}\right)$; ASD = average sunshine duration $(\mathrm{h})$; ANRD = average number of rainy days; MATP $=$ monthly average total precipitation $(\mathrm{mm})$; MaxT $=$ maximum temperature $\left({ }^{\circ} \mathrm{C}\right) ; \operatorname{MinT}=$ minimum temperature $\left({ }^{\circ} \mathrm{C}\right)$

Upon examining the results of the table, it is observed that there are big differences between the meteorological data of the cities. The most significant difference is the amount of precipitation which is very important for plant development. While the annual average precipitation in Rize province is $2304.1 \mathrm{~mm}$, this figure decreases to $384.9 \mathrm{~mm}$ in Kayseri, where the continental climate is dominant. There is approximately a 6-time difference between the two figures. A similar situation is observed between the temperature values. It is noteworthy that there are huge differences between the cities, especially in minimum temperatures. For example, the minimum temperature is $-4.6{ }^{\circ} \mathrm{C}$ in Antalya, where the Mediterranean climate type is observed, while this figure is $-32.5^{\circ} \mathrm{C}$ in Kayseri where the continental climate is observed (Fig. 1). 


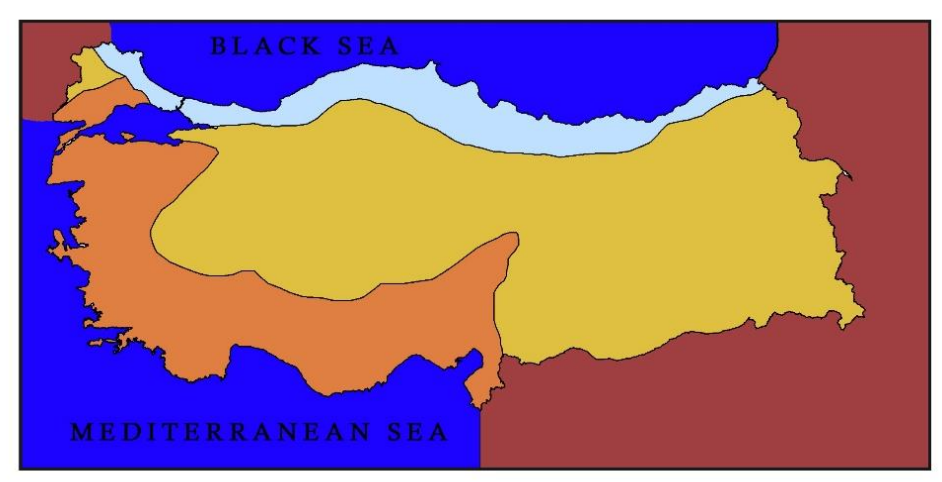

TERRESTRIAL CLIMATE

MEDITERRANEAN SEA CLIMATE

BLACK SEA CLIMATE

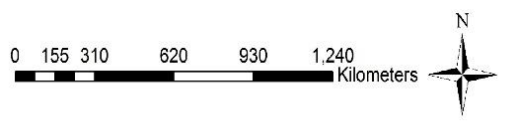

Figure 1. Showing climate type in Turkey

\section{Method}

Within the scope of the study, plane leaves were collected from the parks in the centers of the provinces at the end of September. A total of ten pieces of leaves were collected from each city and each leaf was made up of three pieces. Leaf specimens were collected from mature trees. The areas where the samples were collected are also shown in the map (Fig. 2). The GPS coordinates of the sampling of cities are following: Bartin $41^{\circ} 38^{\prime} 15.3744^{\prime \prime}$ N $32^{\circ} 20^{\prime} 1.7268^{\prime \prime}$ E; Samsun $40^{\circ} 50^{\prime} 12.5^{\prime \prime N} 34^{\circ} 52^{\prime} 28.9^{\prime \prime}$ E; Rize $41^{\circ} 1^{\prime} 31.8468^{\prime \prime} \mathrm{N} 40^{\circ} 31^{\prime} 3.5976^{\prime \prime} \mathrm{E}$; Canakkale 39 $27^{\prime} 12.0^{\prime \prime} \mathrm{N} 26^{\circ} 03^{\prime} 48.9^{\prime \prime} \mathrm{E}$; Ankara $38^{\circ} 40^{\prime} 11.9^{\prime \prime} \mathrm{N} 30^{\circ} 50^{\prime} 03.2^{\prime \prime} \mathrm{E}$; İzmir $37^{\circ} 49^{\prime} 06.9^{\prime \prime} \mathrm{N} 26^{\circ} 13^{\prime} 48.7^{\prime \prime E}$; Antalya

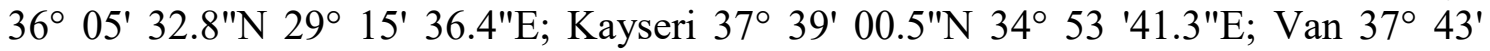
$48.4^{\prime \prime} \mathrm{N} 42^{\circ} 39^{\prime} 42.8^{\prime \prime} \mathrm{E}$

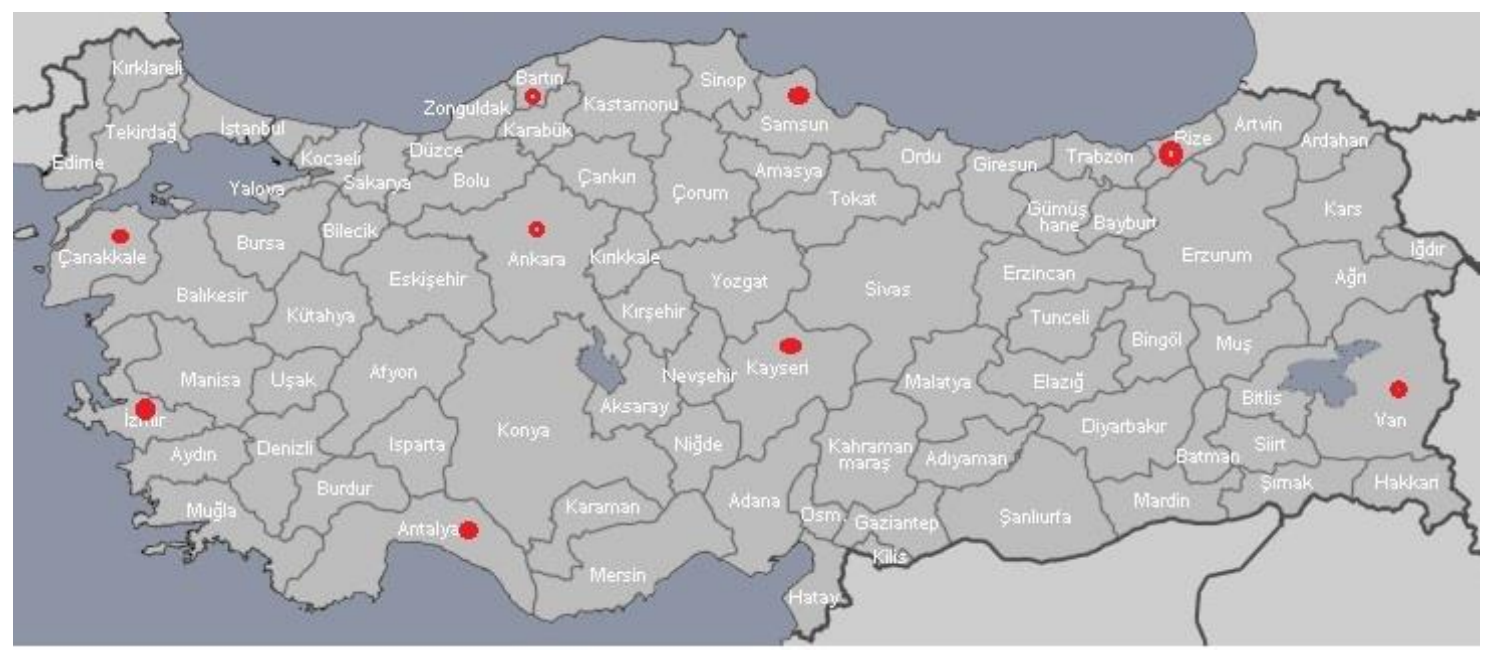

Figure 2. The locations of cities where the leaves samples were taken 
The samples of the mature leaves collected were pressed and brought to the laboratory. Samples were taken from the leaves brought to the laboratory and examined under an electron microscope. With the help of a Scanning Electron Microscope (SEM), scaled images were obtained from the lower side of the leaf blades and areas close to the middle sections. Files with the ".jpeg" extension were created from the obtained images. The points, where the measurements that were made using the "ImageJ" computer measurement program in order to perform micromorphological measurements of the leaves after these processes were completed, are shown in Figure 3.

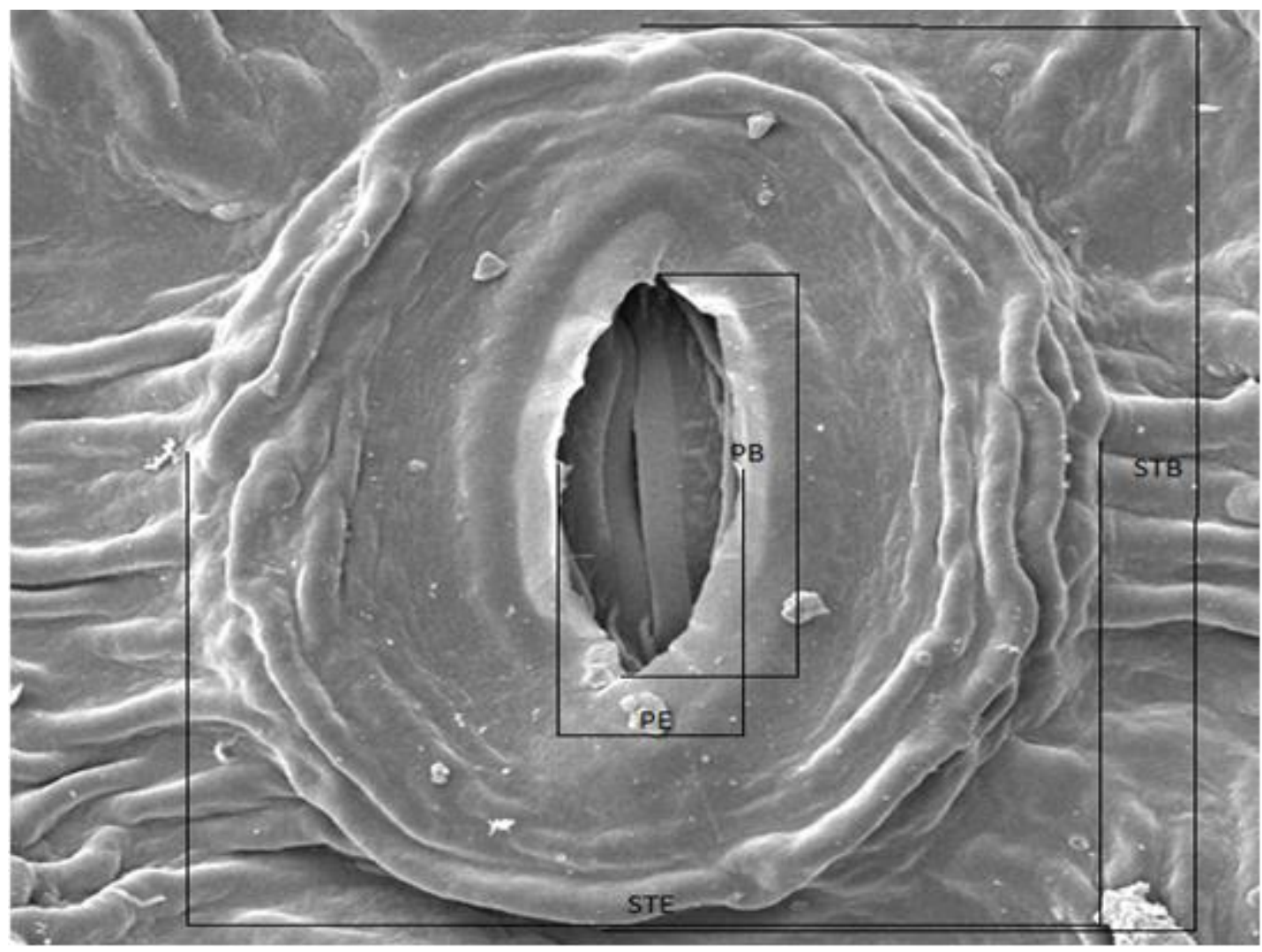

Figure 3. Measurement of micromorphological characteristics. STL: stoma length, STW: stoma width, PL: pore length, PW: pore width, STD: stoma density $\left(1 \mathrm{~mm}^{2}\right.$ in area)

The data were analyzed with the help of SPSS packaged software, and the variance analysis and Duncan's test were applied to the data. As a result, correlation analysis was applied to the data in order to reveal the correlation of the characteristics with each other and with the climate parameters. The correlation coefficient varies between 0 and -1 or +1 and determines the direction of the correlation. If the sample correlation coefficient is equal to 0 , it means that there is no linear connection between the two variables. As this value increases, the correlation between the two variables begins to increase and reaches the highest level when it is 1 (Cohen, 1988). According to Cohen, the correlation between the two variables is weak if the correlation coefficient is between 0.10-0.29 and moderate between 0.30-0.49 and strong between 0.50-1.0. The correlation analysis results obtained in the study were interpreted, and whether the correlation between the characteristics and climate parameters was statistically significant, the correlation direction and strength were interpreted. 


\section{Results}

\section{Change in micromorphological characteristics depending on climate types}

Together with the results of the variance analysis and Duncan's test performed in order to determine the change in micromorphological characteristics of the species grown in different climate types depending on the climate type, the average values of the micromorphological characteristics based on the climate type are presented in Table 2 .

Table 2. Change in micromorphological characteristics depending on climate type

\begin{tabular}{c|c|c|c|c|c}
\hline \multirow{2}{*}{ Climate Type } & \multicolumn{5}{|c}{ Characters } \\
\cline { 2 - 6 } & STL $(\boldsymbol{\mu m})$ & STW $(\boldsymbol{\mu m})$ & PL $(\boldsymbol{\mu m})$ & PW $(\boldsymbol{\mu m})$ & STD $(\boldsymbol{\mu m})$ \\
\hline Continental & 30.776 & $25.364 \mathrm{~b}$ & 14.764 & 7.037 & 391.56 \\
Mediterranean & 28.687 & $21.956 \mathrm{a}$ & 13.382 & 6.441 & 313.78 \\
Black Sea & 29.105 & $24.448 \mathrm{ab}$ & 13.279 & 6.842 & 340.00 \\
F Value & $1.303 \mathrm{~ns}$ & $3.736^{*}$ & $2.064 \mathrm{~ns}$ & $0.414 \mathrm{~ns}$ & $1.480 \mathrm{~ns}$ \\
\hline
\end{tabular}

*Significant level is at 0.05 . The letters a, b, c, etc. means according to Duncan test results; show that the group is located. The means of following abbreviations are STL: stoma length; STW: stoma width; PL: pore length; PW: pore width; STD: stoma density

Upon examining the table values, it is observed that there is no statistically significant difference between climate types with at least $95 \%$ confidence level in terms of characteristics other than STW. On the other hand, there are significant differences at a 99\% confidence level between the climate types in terms of STW. As a result of Duncan's test, two homogeneous groups were formed. The lowest value $(21.956 \mu \mathrm{m})$ was obtained in the Mediterranean climate type, while the value obtained in the Black Sea climate type $(24.448 \mu \mathrm{m})$ took place in both homogeneous groups. The value obtained in the continental climate type $(25.364 \mu \mathrm{m})$ took place in the last homogeneous group.

\section{Change in micromorphological characteristics depending on cities}

Variance analysis was performed to determine the micromorphological characteristics of the species collected from the aforementioned cities. The $F$ value and significance level obtained as a result of the variance analysis and the groupings consisting of the average values and Duncan's test are presented in Table 3.

Upon examining the table values, it is observed that there are statistically significant differences between the cities with at least 95\% confidence level in terms of all characteristics except for STD. In terms of STD, there are no statistically significant differences between the cities at least $95 \%$ confidence level.

According to Duncan's test results, STL values were collected in three homogeneous groups. As a result of Duncan's test, Antalya with the lowest value $(23.481 \mu \mathrm{m})$ took place in the first homogeneous group, while Bartın, Kayseri, and Samsun took place in the second homogeneous group, and Ankara and Çanakkale with the highest value $(33.163 \mu \mathrm{m})$ took place in the third homogeneous group. Izmir, Rize, and Van took place in both the second and third homogeneous groups. In terms of STW, Antalya with the lowest value $(17.669 \mu \mathrm{m})$ formed the first homogeneous group, while Ankara with 
the highest value $(27.274 \mu \mathrm{m})$ formed the last homogeneous group together with Van, Samsun, Çanakkale, and Rize. Bartın, Kayseri, and Rize formed the second homogeneous group.

Table 3. Change in micromorphological characteristics depending on cities

\begin{tabular}{|c|c|c|c|c|c|c|}
\hline Climate & Provinces & $\operatorname{STL}(\mu \mathrm{m})$ & $\operatorname{STW}(\mu \mathrm{m})$ & $\mathbf{P L}(\boldsymbol{\mu m})$ & PW ( $\boldsymbol{\mu m})$ & $\operatorname{STD}(\mu \mathrm{m})$ \\
\hline \multirow{3}{*}{ 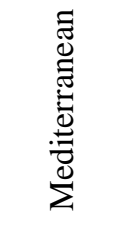 } & Antalya & $23.481 \mathrm{a}$ & $17.669 \mathrm{a}$ & $10.522 \mathrm{a}$ & $4.506 \mathrm{a}$ & 301.33 \\
\hline & İzmir & $29.536 \mathrm{bc}$ & $21.765 \mathrm{~b}$ & $14.473 \mathrm{bc}$ & $6.675 \mathrm{bcd}$ & 349.33 \\
\hline & Çanakkale & $33.045 \mathrm{c}$ & $26.435 \mathrm{c}$ & $15.152 \mathrm{c}$ & $8.142 \mathrm{de}$ & 290.67 \\
\hline \multirow{3}{*}{ 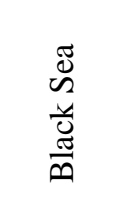 } & Samsun & $28.756 \mathrm{~b}$ & $27.049 \mathrm{c}$ & $14.309 \mathrm{bc}$ & $8.764 \mathrm{e}$ & 378.67 \\
\hline & Bartın & $28.402 \mathrm{~b}$ & $20.773 \mathrm{~b}$ & $13.359 \mathrm{bc}$ & $5.597 \mathrm{ab}$ & 321.33 \\
\hline & Rize & $30.158 \mathrm{bc}$ & $25.521 \mathrm{c}$ & $12.168 \mathrm{ab}$ & $6.167 \mathrm{abc}$ & 320.00 \\
\hline \multirow{4}{*}{ 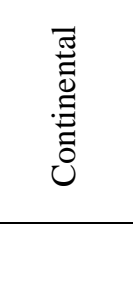 } & Van & $31.433 \mathrm{bc}$ & $27.164 \mathrm{c}$ & $14.872 \mathrm{c}$ & 7.120 bcde & 457.33 \\
\hline & Kayseri & $27.732 b$ & $21.655 \mathrm{~b}$ & $13.551 \mathrm{bc}$ & $5.952 \mathrm{ab}$ & 290.67 \\
\hline & Ankara & $33.163 \mathrm{c}$ & $27.274 \mathrm{c}$ & $15.867 \mathrm{c}$ & 8.039 cde & 338.67 \\
\hline & F Value & $5.924 * * *$ & $18.324 * * *$ & $3.979 * *$ & $5.051 * * *$ & $0.727 \mathrm{~ns}$ \\
\hline
\end{tabular}

*Significant level is at $0.05 ; * *$ significant level is at $0.01 ; * * *$ significant level is at 0.001 level. The letters a, b, c, etc. means according to Duncan test results; show that the group is located. The means of following abbreviations are STL: stoma length; STW: stoma width; PL: pore length; PW: pore width; STD: stoma density

PL values were collected in three homogenous groups based on cities. Antalya which had the lowest value $(10.522 \mu \mathrm{m})$ took place only in the first homogeneous group, while Ankara $(15.867 \mu \mathrm{m})$, Çanakkale $(15.152 \mu \mathrm{m})$ and Van $(14.872 \mu \mathrm{m})$ which had the highest values were only in the last homogeneous group. Rize which had the second lowest value $(12.168 \mu \mathrm{m})$ took place in the second homogeneous group, while other cities, Bartın, Kayseri, Samsun, and Izmir took place in both the second and third homogeneous groups. The cities were gathered in five homogeneous groups in terms of the PW value. Antalya which had the lowest value $(4.506 \mu \mathrm{m})$ took place only in the first homogeneous group, while Samsun which had the highest value $(8.764 \mu \mathrm{m})$ took place only in the last homogeneous group. Regarding the other cities, Bartın and Kayseri were included in the first and second homogeneous groups, Rize was included in the first, second and third homogeneous groups, Izmir was included in the second, third and fourth homogeneous groups, Van was included in the second, third, fourth and fifth homogeneous groups, Ankara was included in the third, fourth and fifth homogeneous groups, and Çanakkale was included in the fourth and fifth homogeneous groups.

As a result of the variance analysis of the STD characteristic based on cities, it was determined that the change in the STD values based on cities was not statistically significant at least 95\% confidence level. Therefore, Duncan's test was not applied to 
the change in STD characteristic based on cities. When the change in STD based on cities is examined, it is observed that the values vary between 290.67 units $/ \mathrm{mm}^{2}$ and 457.33 units $/ \mathrm{mm}^{2}$. The lowest STD value was obtained in Çanakkale, while the highest STD value was obtained in Van.

\section{Results of the correlation analysis}

Correlation analysis was performed to determine the correlation between micromorphological characteristics and climate values, and the results are presented in Table 4.

Table 4. Results of the correlation analysis related to micromorphological characteristics

\begin{tabular}{c|c|c|c|c|c}
\hline & STL $(\boldsymbol{\mu m})$ & STW $(\boldsymbol{\mu m})$ & PL $(\boldsymbol{\mu m})$ & PW $(\boldsymbol{\mu m})$ & STD $(\boldsymbol{\mu m})$ \\
\hline STL & $0.740^{* *}$ & & & & \\
PL & $0.730^{* *}$ & $0.594^{* *}$ & & & \\
PW & $0.397^{* *}$ & $0.618^{* *}$ & $0.562^{* *}$ & & \\
STD & 0.110 & 0.128 & 0.115 & 0.150 & \\
$\mathrm{~T}_{\mathrm{a}}\left({ }^{\circ} \mathrm{C}\right)$ & $-0.347^{*}$ & $-0.450^{* *}$ & $-0.329^{*}$ & -0.188 & -0.326 \\
$\mathrm{~T}_{\max }\left({ }^{\circ} \mathrm{C}\right)$ & $-0.450^{* *}$ & $-0.665^{* *}$ & $-0.359^{*}$ & $-0.342^{*}$ & -0.323 \\
$\mathrm{~T}_{\min }\left({ }^{\circ} \mathrm{C}\right)$ & -0.240 & -0.267 & -0.285 & -0.079 & -0.308 \\
$\mathrm{ASD}(\mathrm{hrs})$ & -0.128 & $-0.326^{*}$ & 0.037 & -0.156 & 0.056 \\
$\mathrm{ANRD}$ & 0.046 & 0.223 & -0.124 & 0.021 & -0.020 \\
$\operatorname{MATP}(\mathrm{mm})$ & -0.159 & -0.120 & $-0.429^{* *}$ & -0.276 & -0.214 \\
$\operatorname{MaxT}\left({ }^{\circ} \mathrm{C}\right)$ & $-0.497^{* *}$ & $-0.777^{* *}$ & $-0.318^{*}$ & $-0.457^{* *}$ & -0.236 \\
$\operatorname{MinT}\left({ }^{\circ} \mathrm{C}\right)$ & -0.233 & -0.211 & $-0.325^{*}$ & -0.081 & -0.303 \\
\hline
\end{tabular}

$*$ Significant level is at 0.05 ; **significant level is at 0.01 ; ***significant level is at 0.001 level. The means of following abbreviations are STL: stoma length; STW: stoma width; PL: pore length; PW: pore width; STD: stoma density

Upon examining the table values, it is observed that the correlations between all characteristics other than STD are statistically significant. Only the correlation of STD with STL was statistically significant. It was determined that all of the correlations between micromorphological characteristics were positive, only the correlation between STL and PW was moderate and the correlations between the other characteristics were strong.

When the correlation between climate data and micromorphological characteristics is examined, it is observed that no correlation of STD with the climate parameters is statistically significant. In addition to this, it is observed that the correlation of MaxT $\left({ }^{\circ} \mathrm{C}\right)$ and $\mathrm{T}_{\max }\left({ }^{\circ} \mathrm{C}\right)$ with all micromorphological characteristics and the correlation of $\mathrm{T}_{\mathrm{a}}$ $\left({ }^{\circ} \mathrm{C}\right)$ with micromorphological characteristics other than PW are statistically significant. In addition to these, it was determined that the correlation of MinT $\left({ }^{\circ} \mathrm{C}\right)$ with PL, the correlation of ASD (hrs) with STW, and the correlation of MATP (mm) with PL were statistically significant.

It is noteworthy that the statistically significant correlations found between climate data and micromorphological characteristics are all negative. The strongest correlations among these are between STW and ANRD, and $\mathrm{T}_{\max }\left({ }^{\circ} \mathrm{C}\right)$. While these correlations are negative and strong, other correlations are moderate and strong. 


\section{Discussion}

The plants used in the study were collected from plants that were planted for landscaping in city centers. In landscape studies, practitioners may change microenvironmental conditions to a certain extent. This situation causes species to be cultivated outside of their natural distribution areas (Cetin et al., 2018a). In this case, the effects of the dominant climate type in the area where the plant is grown are limited. For example, in this study, there was no correlation found between the amount of precipitation and the characteristics examined at the expected level. However, there is a very strong correlation between precipitation, namely water status, and plant development (Sevik and Cetin, 2015; Biber and Kara, 2012; Li et al., 2015; Marathe and Babu, 2017; Dixon et al., 2015).

Studies on the micromorphological characteristics of plants indicate that the water status and stomatal characteristics are closely related (Yang and Wang, 2001; Zhang et al., 2006; Liu et al., 2006). The fact that there was no significant difference between the characteristics examined and the climatic parameters in this study is probably due to the alteration of micro conditions by maintenance work on plants in landscape applications because irrigation applications, climatic, fertilizing applications, edaphic, spraying and pruning applications may also change biological conditions significantly.

In the studies, it is stated that the morphological and micromorphological characteristics of plant leaves are related to stress conditions. Factors such as high and low temperatures, salinity, oxygen shortage, and light stress as well as water status can significantly affect plant growth performance and characteristics (Kulaç, 2010; Xu and Zhou, 2008; Sevik et al., 2016; Topacoglu et al., 2016; Sevik and Karaca, 2016; Zhao et al., 2001; Romero-Aranda et al., 2001). Therefore, stomatal characteristics may change depending on many environmental conditions such as light, humidity, drought, and $\mathrm{CO}_{2}$ (Banon et al., 2004; Beerling et al., 1997). In fact, it is stated that stomatal characteristics may change depending on factors such as traffic density because many unpredictable environmental factors may affect the growth, development and morphological characteristics of plants by creating stress effects (Sevik et al., 2017, 2018; Cetin et al., 2018a, b; Turkyilmaz, 2018a, b, c).

Plants do not easily encounter stress factors due to the climate in their natural habitats. However, since the plants used in landscape studies are cultivated outside of their natural habitat, they are more likely to encounter climate-induced stress conditions. The damages and effects on plant morphology caused by stress factors vary depending on the type, tolerance, and adaptability of the plant (Madhova Rao, 2005; Kadıoglu, 2004).

Besides the mentioned conditions, the effect of external factors on plants can also affect plant development and its morphological characteristics. Factors such as pruning, hormone applications, spraying, shading and fertilization were demonstrated to be effective on the morphological and micromorphological characteristics of the plant (Knecht and Orton, 1970; Ferris et al., 1996; Pearson et al., 1995; Guney et al., 2016; Sevik and Cetin, 2016; Aydemir Özcan, 2017).

In addition, one of the factors that determine the reaction of the plant to the environmental conditions is the genetic structure. Morphological and physiological characteristics in plants are shaped by the interaction of genetic structure and environmental factors. Therefore, there are many factors affecting morphological characteristics. Many factors such as precipitation, temperature, stress factors, light, air pollution and soil structure affect the morphological characteristics of plants (Gratani, 
2014; Peguero-Pina et al., 2014; Jochner et al., 2015; Majeed et al., 2015; Jud et al., 2016; Ren et al., 2018). The response of the plant to these factors is closely related to the genetic structure of the plant (Sevik et al., 2016, 2017). Plants of the same species can react differently to different stress conditions (Topacoglu et al., 2016). This is related to the genetic structure of the plant. As a matter of fact, it is stated that there may be significant differences between morphological and micromorphological characteristics of the plants grown in the same environment besides their growth performance (Sevik et al., 2016, 2017; Hrivnák et al., 2017).

\section{Conclusion}

As a result of the study, it was determined that there were huge differences between the data obtained from the cities located in the regions where the same climate type is dominant. For example, while the lowest value for STL was obtained in Antalya province, the second highest value was obtained in Çanakkale. On the other hand, the lowest value for PL was obtained in Antalya, while the second highest value was obtained in Izmir. However, three of the cities of Antalya, Çanakkale, and Izmir are located in areas where the Mediterranean climate type is dominant.

The results of the correlation analysis also support these results. According to the results of the correlation analysis, there was no correlation between the climate parameters and micromorphological characteristics at the expected level. Similar results were obtained for morphometric characteristics. It may be interpreted that factors other than climate are more effective on micromorphological and morphometric characteristics.

As a result of the study, no significant effect of the climate could be detected on the characteristics examined in the study. The possible causes are explained above. This situation can be interpreted as morphological characteristics are shaped by many environmental factors and genetic structure besides climate. In this case, it can be suggested to increase and diversify studies on the subject in order to determine how and under which conditions micromorphological characteristics are shaped in particular. In these studies, the diversification of the effects of environmental and genetic factors and examination of the changes caused by only one factor may provide more accurate data.

If a plant with high water demand is grown in a dry area, its water needs can be met by regular irrigation. Therefore, the micro conditions in which the plant is grown may be quite different from the main climate type. A similar situation applies to edaphic factors. Thus, micro-environmental conditions in plants used for landscaping can be quite different from the edaphic and climatic conditions of the region, and the microenvironmental conditions can strongly affect the growth performance of the plant. Therefore, it is difficult to determine the effect of climate on micromorphological characteristics of the plant in the studies conducted on the plants collected from these areas. Therefore, future studies to be carried out on natural plant species if they cannot be conducted in control environments may lead to more accurate data for determining the effect of climate on the micromorphological characteristics of the plant.

\section{REFERENCES}

[1] Akkemik, Ü. (ed.) (2014): Natural-Exotic Trees and Shrubs of Turkey. - Publications of the General Directorate of Forestry, Ankara. 
[2] Aydemir Özcan, A. G. (2017): Effect of Shading and Fertilization Applications on Flower Yield and Growth in Lavender (Lavandula angustifolia Miller.). - Kastamonu University, Graduate School of Natural and Applied Sciences, Department of Forest Engineering, Master Thesis, Kastamonu.

[3] Banon, S., Fernandez, J. A., Franco, J. A., Torrecillas, A., Alarcón, J. J., Sánchez-Blanco, M. J. (2004): Effects of water stress and night temperature preconditioning on water relations and morphological and anatomical changes of Lotus creticus plants. - Scientia Horticulturae 101(3): 333-342.

[4] Beerling, D. J., Kelly, C. K., Salisbury, E. J. (1997): Stomatal density of temperature woodland plants over the past seven decades of $\mathrm{CO} 2$ increase: a comparison of Salisbury (1927) with contemporary data. - American Journal of Botany 84: 1572-1583.

[5] Biber, Ç., Kara, T. (2012): Plant water consumption of maize plant and limited irrigation practices. - Journal of Anatolian Agricultural Sciences 21(1): 140-146.

[6] Cetin M, Sevik H, Saat A (2017): Indoor air quality: the samples of Safranbolu Bulak Mencilis Cave. - Fresenius Environmental Bulletin 26(10): 5965-5970.

[7] Cetin, M., Sevik, H. (2016a): Assessing Ecotourism Potential Areas through a Case Study in Ilgaz Mountain National Park. - In: Butowski, L. (ed.) Tourism - From Empirical Research towards Practical Application. Chapter 5. InTech, London. DOI: $10.5772 / 62573$.

[8] Cetin, M., Sevik, H. (2016b): The change of air quality in Kastamonu city in terms of particulate matter and $\mathrm{CO}_{2}$ amount. - Oxidation Communications 39(4-II): 3394-3401.

[9] Cetin, M., Sevik, H., Yigit, N., Ozel, H. B., Aricak, B., Varol, T. (2018a): The variable of leaf micromorphogical characters on grown in distinct climate conditions in some landscape plants. - Fresenius Environmental Bulletin 27(5): 3206-3211.

[10] Cetin, M., Onac, A. K., Sevik, H., Sen, B. (2018b): Temporal and regional change of some air pollution parameters in Bursa. - Air Quality, Atmosphere \& Health. https://doi.org/10.1007/s11869-018-00657-6.

[11] Cohen, J. (1988): Statistical Power Analysis for the Behavioral Sciences (2nd Ed.). Lawrence Erlbaum Associates, Hillsdale, NJ.

[12] Dixon, E. K., Strik, B. C., Valenzuela-Estrada, L. R., Bryla, D. R. (2015): Weed management, training, and irrigation practices for organic production of trailing blackberry: I. Mature plant growth and fruit production. - HortScience 50(8): 1165-1177.

[13] Erna, L. (2009): Factors affecting upper-middle and upper-income housing prices in urban development areas of Istanbul. - Master Thesis, Istanbul Technical University, Institute of Science and Technology, Istanbul.

[14] Ertuğrul, M., Varol, T., Özel, H. B. (2014): Climate changes in prospect for the West Black Sea Forests. - International Journal of Bartin Faculty of Forestry 16(23-24): 35-43.

[15] Ferris, R., Nijs, I., Beaeghe, T., Impens, I. (1996): Elevated $\mathrm{CO}_{2}$ and temperature have different effects on leaf anatomy of perennial ryegrass in spring and summer. - Annals of Botany 78: 489-497.

[16] Gratani, L. (2014): Plant phenotypic plasticity in response to environmental factors. Advances in Botany 2014: 1-17.

[17] Güler, Z., Dursun, A., Ozkan, D. (2017): Volatile compounds in the leaf of plane tree (Platanus orientalis) with solid phase microextraction (SPME) technique. - Int. J. Sec. Metabolite, Vol. 4(3): 167-176.

[18] Guney, K., Cetin, M., Sevik, H., Guney, K. B. (2016): Influence of germination percentage and morphological properties of some hormones practice on Lilium martagon L. seeds. - Oxidation Communications 39(1-II): 466-474.

[19] Hrivnák, M., Paule, L., Krajmerová, D., Kulac, S., Sevik, H., Turna, I., Tvauri, I., Gömöry, D. (2017): Genetic variation in Tertiary relics: The case of easternMediterranean Abies (Pinaceae). - Ecology and Evolution 7(23): 10018-10030. 
[20] Jochner, S., Markevych, I., Beck, I., Traidl-Hoffmann, C., Heinrich, J., Menzel, A. (2015): The effects of short-and long-term air pollutants on plant phenology and leaf characteristics. - Environmental Pollution 206: 382-389.

[21] Jud, W., Vanzo, E., Li, Z., Ghirardo, A., Zimmer, I., Sharkey, T. D., Hansel, A., Schnitzler, J. P. (2016): Effects of Heat and drought stress on post-illumination bursts of volatile organic compounds in isoprene-emitting and non-emitting poplar. - Plant, Cell \& Environment 39(6): 1204-1215.

[22] Kadığlu, A. (2004): Bitki Fizyolojisi. - Lokman Yayın, Trabzon.

[23] Kantarc1, M. D., Özel, H. B., Ertekin, M., Kırdar, E. (2011): An evaluation on the adaptation of six tree species used in the afforestation of Konya-Karapinar to the steppe habitat. - The Journal of Bartın Forestry Faculty 13(19): 107-127.

[24] Karakuş, O. (2018): Variation of some leaf micromorphological characteristics in Platanus orientalis L. individuals grown in different growing conditions. - Master Thesis, Kastamonu University, Kastamonu.

[25] Kaya, L. G., Kaynakci-Elinc, Z., Yucedag, C., Cetin, M. (2018): Environmental outdoor plant preferences: a practical approach for choosing outdoor plants in urban or suburban residential areas in Antalya, Turkey. - Fresenius Environmental Bulletin 27(12): 79457952.

[26] Knecht, G. N., Orton, E. R. (1970): Stomata density in relation to winter hardiness of Ilex opaca Ait. - Journal of the American Society for Horticultural Science 95: 341-345.

[27] Kulaç, Ş. (2010): Investigation of some morphological physiological and biochemical changes in yellow pine (Pinus sylvestris L.) seedlings exposed to drought stress. - Ph.D. Thesis, Karadeniz Technical University, Institute of Science and Technology, Trabzon.

[28] Li, C., Lei, J., Zhao, Y., Xu, X., Li, S. (2015): Effect of saline water irrigation on soil development and plant growth in the Taklimakan Desert highway shelterbelt. - Soil and Tillage Research 146: 99-107.

[29] Liu, S., Liu, J., Cao, J., Bai, C., Shi, R. (2006): Stomatal distribution and character analysis of leaf epidermis of jujube under drought stress. - Journal of Anhui Agricultural Science 34: 1315-1318.

[30] Madhova-Rao, K. V., Raghavendra, A. S., Janardhan-Reddy, K. (2005): Physiology and Molecular Biology of Stress Tolerance in Plants. - Springer, Netherlands.

[31] Majeed, A., Abbasi, M. K., Hameed, S., Imran, A., Rahim, N. (2015): Isolation and characterization of plant growth-promoting rhizobacteria from wheat rhizosphere and their effect on plant growth promotion. - Frontiers in Microbiology 6: 198.

[32] Marathe, R. A., Babu, K. D. (2017): Plant growth, nutrient uptake, water use efficiency and yield of pomegranate as affected by irrigation scheduling in loamy soils of semi-arid regions. - The Horticultural Society of India (Regd.) 74(2): 204-209.

[33] Ökmen, M., Yurtsever, H. (2010): Taxation of public rent in the process of urban planning. - Journal of Finance 158: 58-74.

[34] Özel, H. B. (2008): The effect of forest restoration applications on some soil properties of Bartın-Ardıç region. - Journal of Ecology 17(69): 14-19.

[35] Öztürk, A., Seki, N., Yiğit, N. (2017): Woody plant variety in parks and gardens of Taşköprü (Kastamonu) district and evaluation of local compliance. - International Journal of Current Research 9(11): 60857-60861.

[36] Pearson, M., Davies, W. J., Mansfield, T. A. (1995): Asymmetric responses of adaxial and abaxial stomata to elevated $\mathrm{CO}_{2}$ impacts on the control of gas exchange by leaves. Plant, Cell \& Environment 18: 837-843.

[37] Peguero-Pina, J. J., Sancho-Knapik, D., Barrón, E., Camarero, J. J., Vilagrosa, A., GilPelegrín, E. (2014): Morphological and physiological divergences within Quercus ilex support the existence of different ecotypes depending on climatic dryness. - Annals of Botany 114(2): 301-313. 
[38] Ren, X., Zhu, J., Liu, H., Xu, X., Liang, C. (2018): Response of antioxidative system in rice (Oryza sativa) leaves to simulated acid rain stress. - Ecotoxicology and Environmental Safety 148: 851-856.

[39] Romero-Aranda, R., Soria, T., Cuartero, J. (2001): Tomato plant-water uptake and plantwater relationships under saline growth conditions. - Plant Science 160(2): 265-272.

[40] Sevik, H., Cetin, M. (2015): Effects of water stress on seed germination for select landscape plants. - Polish Journal of Environmental Studies 24(2): 689-693.

[41] Sevik, H., Cetin, M. (2016): Effects of some hormone applications on germination and morphological characters of endangered plant species Lilium artvinense L. onion scales. Bulgarian Chemical Communications 48(2): 256-260.

[42] Sevik, H., Karaca, U. (2016): Determining the resistances of some plant species to frost stress through ion leakage method. - Fresenius Environmental Bulletin 25(8): 2745-2750.

[43] Sevik, H., Cetin, M., Kapucu, O. (2016): Effect of light on young structures of Turkish Fir (Abies nordmanniana subsp. bornmulleriana). - Oxidation Communications 39(1-II): 485-492.

[44] Sevik, H., Cetin, M., Kapucu, O., Aricak, B., Canturk, U. (2017): Effects of light on morphologic and stomatal characteristics of Turkish fir needles (Abies nordmanniana subsp. bornmulleriana Mattf.). - Fresenius Environmental Bulletin 26(11): 6579-6587.

[45] Sevik, H., Ozel, H. B., Cetin, M. Ozel, H. U., Erdem, T. (2018): Determination of changes in heavy metal accumulation depending on plant species, plant organism, and traffic density in some landscape plants. - Air Quality, Atmosphere \& Health. https://doi.org/10.1007/s11869-018-0641-x.

[46] Tilki, F., Güner, S., Tüfekçioğlu, A. (2008): Urban forestry and Artvin city urban forestry applications. - Artvin Coruh University, Journal of Forestry Faculty 9(1-2): 92-100.

[47] Topacoglu, O., Sevik, H., Akkuzu, E. (2016): Effects of water stress on germination of Pinus nigra Arnold. Seeds. - Pakistan Journal of Botany 48(2): 447-453.

[48] Turkyilmaz, A., Cetin, M., Sevik, H., Isinkaralar, K., Ahmaida Saleh, E. A. (2018a): Variation of heavy metal accumulation in certain landscaping plants due to traffic density. - Environment, Development and Sustainability. DOI: https://doi.org/10.1007/s10668018-0296-7.

[49] Turkyilmaz, A., Sevik, H., Cetin, M. (2018b): The use of perennial needles as biomonitors for recently accumulated heavy metals. - Landscape and Ecological Engineering 14(1): 115-120.

[50] Turkyilmaz, A., Sevik, H., Cetin, M., Ahmaida Saleh, E. A. (2018c): Changes in heavy metal accumulation depending on traffic density in some landscape plants. - Pol. J. Environ. Stud. 27(5): 2277-2284. DOI: 10.15244/pjoes/78620.

[51] Xu, Z., Zhou, G. (2008): Responses of leaf stomatal density to water status and its relationship with photosynthesis in a grass. - Journal of Experimental Botany 59(12): 3317-3325.

[52] Yang, H. M., Wang, G. X. (2001): Leaf stomatal densities and distribution in Triticum aestivum under drought and $\mathrm{CO}_{2}$ enrichment. - Acta Phytoecologica Sinica 25: 312-316.

[53] Yiğit, N., Öztürk, A., Sevik, H. (2014): Ecological impact of urban forests (example of Kastamonu urban forest). - International Journal of Engineering Sciences \& Research Technology 3(12): 558-562.

[54] Zhang, Y. P., Wang, Z. M., Wu, Y. C., Zhang, X. (2006): Stomatal characteristics of different green organs in wheat under different irrigation regimes. - Acta Agronomica Sinica 32: 70-75.

[55] Zhao, R. X., Zhang, Q. B., Wu, X. Y., Wang, Y. (2001): The effects of drought on epidermal cells and stomatal density of wheat leaves. - Inner Mongolia Agricultural Science and Technology 6: 6-7. 